\title{
Gildesøskende
}

\section{Gilder som mødested i 1400-tallets Norden}

Lars Bisgaard

De skandinaviske samfund i middelalderen var kendetegnet ved at være funktionsopdelte og hierarkiske. For mænd som for kvinder herskede der særskilte ideer om ret opførsel, og hvad hvert køn burde tage sig til og af. Mænd var bønder, håndværkere, krigere og præster, og selv om kvindernes opgaver som regel forudsættes bekendt i kilderne og derfor er vanskeligere at indkredse, så synes de have haft en tilsvarende styrke på andre områder så som i det huslige, i opdragelsen af børn og i særlige typer af arbejder. Med forestillingen om samfundet som en familia, ${ }^{513}$ der med en konge og en dronning i spidsen for hele husholdet, føjedes en hierarkisk opbygning til det funktionsbestemte, og med mandens værnefunktion, der beskyttede husholdet, var der en klar tilstræbt orden og logik til stede.

Mens der ikke er tvivl om, at dette samfundsideal var gennemført i perioden 1500-1800, har flere kvindestudier fra de seneste årtier slået revner i dets middelalderlige overflade. For det første savnes der kilder til at undersøge, om idealforestillingerne blev efterlevet i praksis, og for det andet har punktstudier vist, at kvinder - ikke mindst i senmiddelalderens byer - kunne varetage funktioner, som egentlig var mandens. Det gjaldt ikke mindst blandt håndværkerne. ${ }^{514}$ Situationen er langt fra entydig, for selv samme kvindestudier kan have en tendens til at fokusere på det atypiske og for ikke at tillægge tidens herskende diskurser nok vægt. Kritikken har dog været mest markant af førstegenerationen af kvindeforskere, hvor forestillingerne om ret adfærd og rette gøremål for kønnene alene blev betragtet som ideologier, og ikke som rammer for tidens tænkning. ${ }^{515}$

Ved at gøre kvindestudier til kønsstudier og således ikke udeluk-

513 Helge Paludan, Familia og familie. To europeiske kulturelementers mode $i$ højmiddelalderens Danmark (Århus 1995).

514 Eileen Power, Medieval Women (Cambridge 1975), s. 53ff., Grethe Jacobsen: Kvindeskikkelser og kvindeliv i Danmarks middelalder (København 1986), s. 112-124.

515 F.eks. Nanna Damsholt, Kvindebilledet $i$ dansk højmiddelalder (København 1985). 


\section{MEDELTIDENS GENUS}

ke manden af synsfeltet synes det oplagt at søge enheder i samfundet, hvor mænd og kvinder optrådte side om side. Familien, arbejdslivet på gårdene men også gilderne er sådanne felter. Gildernes organisation og interne liv er mig bekendt ikke undersøgt ud fra et kønsperspektiv. En vigtig grund hertil er, at den dominerende tilgang i studiet af gilderne har været at anskue dem som erhvervsorganisationer enten for købmænd eller håndværkere. Dette har betydet, at mange kvindestudier primært har fokuseret på mestrenes hustruer og deres situation som enker, samt på kvinders mulighed for at udøve erhverv i det hele taget. ${ }^{516}$ Denne forståelse af gilderne har skygget for, at de også tjente som et mødested for mænd og kvinder, ja for forskellige grupper i samfundet i det hele taget. Denne erkendelse er opnået gennem studier af gildernes religiøse opgaver, som netop overskred erhvervets grænser, og satte broderskabets ånd i centrum. Det er i lyset af denne indsigt, at undersøgelsen her tager sit afsæt. For var gilderne et mødested, må materialet kunne aftvinges et svar om mænds og kvinders ageren, når de var sammen. Tilbød gilderne med deres gildedrik og mange sociale gøremål et frirum for samfundets faste regler, eller eksisterede der også her en orden for kønnene?

Svaret skal søges på baggrund af det skandinaviske gildemateriale i sin bredde, det vil sige deres vedtægter, regnskaber, medlemslister $\mathrm{mm}$. Et par markante studier har inden for de sidste par årtier haft et skandinavisk sigte. ${ }^{517}$ Der eksisterer en skævhed i det bevarede kildemateriale, som betyder, at situationen ikke kan beskrives lige grundigt for de enkelte lande. De norske gildevedtægter glimrer så at sige ved deres fravær, de svenske er bevaret i begrænset omfang, mens de danske er mange i antal og righoldige i udtryk. Det gælder samstemmende for de tre lande, at materialet primært stammer fra 1400- og 1500-tallets begyndelse. Dog går dele af det norske og det danske tilbage til 1100- og 1200-tallet.

\footnotetext{
516 Jacobsen (1986); Grethe Jacobsen, Kvinder, køn og købstadslovgivning. 1400-1600 lovfaste mand og arlige kvinder (København 1995).

517 Christoph Anz, Gilden im mittelalterlichen Skandinavien, Veröffentlichungen des Max-Planck-Institut für Geschichte, 139 (Göttingen 1998), Håkon Haugland, Fellesskap og brorskap. En komparativ undersokelse av gildernes sociale, religiøse og rettslige rolle i et utvalg nordiske byer fra midten av 1200-tallet til reformasjonen (Universitetet i Bergen 2012).
} 


\section{KÖN OCH SOCIAL ORGANISATION}

\section{Gilde og broderskab}

I 1496 fik byskriveren i Ystad, Erik Sørensen, den opgave at nedfælde vedtægten for byens smede, klejnsmede som grovsmede. ${ }^{518}$ Smedene havde det ønske, at de gerne ville have den gamle skrå til at fremstå "i et tydeligere sprog". Hvad de hermed mente, kan man kun gisne om, men et godt gæt er, at det drejede sig om en oversættelse fra latin til folkesproget. Gildets dødeliste viser i hvert fald, at smedenes sammenslutning må have eksisteret i lang tid før 1496, for antallet af anførte døde smede overskrider langt, hvad byen har kunnet brødføde i den nærmeste generation bagud.

Ud fra en moderne betragtning er smedenes begrundelse for at slutte sig sammen lidt af en overraskelse. Skråens indledning lyder:

hwor two ællær thre samen komme i mith naffn, ther ær jagh mith i bland them ....

Denne henvisning til Jesu ord (Matthæus 18:20) er identisk med middelalderens mest almindelige begrundelse for broderskabets nytte. At den forefindes i noget så verdsligt som et smedelav er derfor sigende for et gildes natur. ${ }^{519}$ Forordet slutter med at eksemplificere, hvori broderskabet består:

tha børiæs hær then skraa och wilkor, thær smithie innæn Ystædh bør mæth statheligh kiærligheet ath holdhe, hwer mæth thæn annæn, leffwendes mæth thæn leffwende och leffwende mæth thæn døthe. ${ }^{520}$

Altså et broderskab, som kan sikre den rette ånd internt i broderskabet, men også i det større perspektiv mellem smedelavets nuværende medlemmer og dets afdøde. Den fragmentarisk bevarede dødeliste fra gildet viser,

518 DGLM. Danske Gilde- og Lavsskrader fra Middelalderen, udg. v. C. Nyrop, Bd. I-II, Kjøbenhavn (1895-1904), her II, s. 265ff. Tilnavnene i gildets dødeliste signalerer, at det var et bredt smedelav med deltagelse af både grov-, klejn- og våbensmede. Ibid., s. 272-73. Det er nævnt første gang 1465, se Haugland (2012), s. 134.

519 Den genfindes hos murerne i Stockholm med skrå fra 1487. Skrå-ordningar, samlade af G.E. Klemming, (Stockholm 1856), s. 77.

520 DGLM, II (1895-1904), s. 266. 


\section{MEDELTIDENS GENUS}

at dette ønske også blev omsat til virkelighed.

Det hørte til indsigten, som blev erhvervet allerede i 1800-tallets gildeforskning, at et sådant broderskab omfattede begge køn. Erkendelsen er tydeligt til stede i Pappenheims afhandling fra 1885 om de gamle danske værnegilder, men da han var ude i det ærinde at finde germanernes ældgamle fostbroderskab i de skandinaviske gildeskråer, og da denne institution siden blev brugt i den nazistiske propaganda, gled værket naturligt nok i baggrunden allerede fra 1930 'erne. ${ }^{521}$ Det er skæbnens ironi, at kvindernes deltagelse i gilderne gled samme vej. Det blev en anden tysker, Christoph Anz, som rådede bod på skaden. I 1998 plæderede Anz for, at den kristne broderskabstanke var helt central for gilderne, og af samme grund var begge $\mathrm{k} ø \mathrm{n}$ at finde som medlemmer hos dem. ${ }^{522}$ Kvindernes deltagelse formuleres for eksempel meget tydeligt i den udaterede svenske skrå fra Skt. Jørgens gildet ved Kopparberget, hvor det allerede i formålsparagraffen hedder:
Thetta skall allom gilbrødhrom oc syström a riddher sanc- te örgiens gille pa koperberghit witherligit wara, ... Gudhi jomfru maria ok riddher sancte örgien til loff oc äro, som dictath oc schriffwith är, oc fasth hallas skall som här effther sigx..$^{523}$

Det er dette broderskab af levende og døde af begge køn, som forklarer, at gilder havde brug for en værnehelgen. Dette er vigtigt at understrege, for ellers kunne man tro, at det var middelalderkirken, som meget tidligt fik etableret en sammenhæng mellem håndværk og helgenkult, således at bestemte håndværk skulle have deres særlige værnehelgen. Men sammenhængen går den anden vej rundt. Lavene udspringer af gilderne, og det var først, da håndværket udviklede sig mod nye højder, at en kobling fandt sted. I Ystad ses dette tydeligt. Her var gildet viet til helgenen Skt. Eligius. Denne var en yndet beskytter for smedehåndværk, men går man

521 Max Pappenheim, Die Altdänischen Schutzgilden. Ein Beitrag zur Rechtgeschichte der germanischen Genossenschaft. (Breslau 1885).

522 Anz (1998). For opmærksomhed på kvindelig deltagelse, se H.T. Gilkær, 'In honore sancti Kanuti martyris'. Konge og Knudsgilder I det 12. århundrede', Scandia 46 (1980), s. 121-161. 523 Småstycken. Småstycken på Forn Svenska, samlade af G.E. Klemming (Stockholm 18681881), s. 103. Skråen formodes at høre hjemme i slutningen af 1400-tallet. 


\section{KÖN OCH SOCIAL ORGANISATION}

legenden på klingen, var Eligius oprindelig guldsmed, og havde aldrig haft det fjerneste med de grovere dele af smedehvervet at gøre. ${ }^{524}$ Kun en mindre del af helgenskaren oplevede en sådan specialiseret tilknytning, og kun en mindre del af gilderne gjorde brug af sådanne helgener. De fleste gilder valgte beskyttelsen af en almen kendt skikkelse. Det gælder f.eks. Kobberberggildet, som vi så havde valgt Skt. Jørgen/Georg. ${ }^{525}$ På Gotland i 1443 var det Skt. Katarina. Hun blev ofte anvendt af smede, men korrelationen er så svag, at man ikke kan slutte noget om gildets natur ud fra dets valg af værnehelgen. ${ }^{526}$ På Gotland havde gildet i hvert fald ikke det mindste med smede at gøre, men uagtet patronvalg var broderskabstanken her den samme:
Gudz nampn sei lofwat ock ährat i allom thingom. Rätwi- selika bär thet wäl til, at kärleiker sey millan Christna Människior, änkallika millan them, som järu i brydralagh, i S. Catharinæ gijldha. ${ }^{527}$

Samlet kan man definere et gilde som et broderskab, men uden blodet som den samlende faktor, som det var i slægten. Bærende var gensidige forpligtelser, både overfor levende og døde. Det var eksklusivt i den forstand, at den gensidige hjælp kun gjaldt dem, der faldt inden for kriterierne for optagelse, typisk et geografisk tilhørsforhold, fælles erhverv eller særlige religiøse opgaver.

Hermed tegner der sig et billede af gilderne som langt mere åbne sammenslutninger end antaget i ældre forskning. Og dermed også en forståelse af gildet som et sted, hvor forskellige folk kunne mødes. ${ }^{528}$ Før dette nærmere undersøges, er det dog vigtigt at få et andet forhold på plads, nemlig forholdet mellem ledelse og broderskab. Man kan sige, at de fleste gilder havde to strenge i deres virke. På den ene side var der den

524 Lars Bisgaard, De glemte altre. Gildernes religiose opgaver i senmiddelalderens Danmark. (Odense 2001), Planche 4 (s. 202) og s. 371.

525 Flere har forsøgt at knytte Skt. Jørgen og ridderskabet sammen, og selv om der synes at være et vist sammenfald, kan helgenens brug ikke alene indskrænkes til denne gruppe, hvad eksemplet med gildet fra Kobbarberget viser.

526 Bisgaard (2001), s. 300ff.

527 Småstycken (1868-1881), s. 149.

528 Lars Bisgaard \& Lars Boje Mortensen, Guilds, Towns and Cultural Transmission in the North (Odense 2013). 


\section{MEDELTIDENS GENUS}

nedarvede åbne religiøse struktur, hvis iboende logik var, at jo flere der deltog, desto stærkere ville gildet stå. Men dette skal sammenholdes med, at et gilde jo var tilknyttet en lokalitet, et erhverv eller en specifik religiøs opgave, som gav det en særlig farve og personkreds. Det siger sig selv, at kontrollen med gildet gerne skulle forblive hos denne inderkreds.

Denne tostrengede struktur hos gilderne, som først erkendes, når man arbejder sig ned i materialet, giver sig næsten aldrig direkte udtryk i vedtægterne. Måske skyldes det, at man holdt fast i en ældre tradition for skråens affattelse, som tiden egentlig var løbet fra, men som for en konservativ tænkning, hvor sædvanen var tidens rettesnor, gav mening. Forklaringen kan også være politisk, for så vidt som det var i denne form af skråen, at gilderne i 1200-tallets strid med kirkelige og kongelige myndigheder havde fået det blå stempel, og derfor var det klogest ikke at udfordre egen anerkendelse ved at lave for meget om. ${ }^{529}$ Eller måske skal det forklares ved, at mundtligt overleverede skråer nu engang var lettest at huske ved en enkelt komposition. Det sidste mindes man om, når kødmangerne i Stockholm så sent som 1477 forklarende skriver, at den mundtlige overlevering hidtil har været dem nok:

wij kötmaangare embethet ok companij här i stocholm os aff aldher haffua haldhit ok rettat epter godha gambla sidwenio vthan skriffter ok skraa til thenna dagh.... ${ }^{530}$

Øjensynligt var samtiden godt klar over, at skrå og virkelighed ikke altid stemte overens for gildernes vedkommende. Det gjaldt i hvert fald i de større byer, hvor lavene som bekendt tidligst opnåede særlige rettigheder. Her begyndte magistraterne nemlig at udstede særskilte rettighedsbreve for lavene, som anvendte statutter som i broderskabsskråerne. Malmø kan tjene som et eksempel. I begyndelsen af 1400-tallet fik rebvinderne, skinderne, bagerne og smedene skråer udstedt af magistraten. Smedene fik som de sidste en aftale i stand i 1433, og ser vi nærmere på deres vedtægt, samler den sig udelukkende om smedemestrenes embeder og

529 Christoph Anz, 'Gildernes form og funksjon i middelalderens Skandinavia', i Lars Bisgaard \& Leif Søndergaard (red.), Gilder, lav og broderskaber i middelalderens Danmark, (Odense 2002), s. $21 \mathrm{ff}$.

530 Skrå-ordningar (1856), s. 47. Sammenlign Bisgaard (2001), s. 42f. Problemet er ikke tilbundsgående undersøgt men kunne fortjene det. 


\section{KÖN OCH SOCIAL ORGANISATION}

deres privilegier. De enkelte bestemmelser omhandler praktiske ting, som hvordan man bliver mester, hvordan svendenes oplæring skal være, og hvad man er pligtig at yde bystyret etc. Vidste man ikke bedre, skulle man ikke tro, at smedene i Ystad, hvis skrå er behandlet ovenfor, og smedene i Malmø var underkastet vidt forskellige regler, og stammede fra hver sin tid. Men det er ikke tilfældet. Det er blot to forskellige tilgange, hvor henholdsvis ledelse/funktion og broderskab er i centrum. Således kaldes indehaverne af smedembederne i Malmø konsekvent for brødre i byens privilegier, og dermed er der en terminologi til stede som i Ystad. Det sker f.eks. i paragraf 9:

Item skal ængen æmbedis brother i thettæ forscreffnæ æmbede lokke nagher sin methebrothers swen vt aff hans thiæneste, før hans stæffne dagh komber... ${ }^{531}$

Dermed tegner der sig et billede af to hovedoverleveringsformer for gildernes vedtægter, som hver især igen har sine egne varianter, og de vil vægte oplysningerne om sammenslutningen vidt forskelligt. Byens myndigheder var interesseret i de rettigheder, som et gilde måtte besidde indadtil i byen, ligesom reglerne for at afgøre eventuelle tvister mellem by og gilde eller inden for gildet måtte stå højt på agendaen. Og skråen er da givet til gildet af instanser ude fra. Som skindernes skrå fra Malmø i 1429 præcist udsiger det:

Item thenne forskreffna statuta, som kallas skra, haffwa wi grangiwelighe hørt ok iffwerransagat, hwer artikæl fra annar... ${ }^{532}$

I den anden overlevering er broderskabet i centrum, og det betones igen og igen, hvorledes fred og samdrægtighed skal herske indadtil i gildet og få det til at stå stærkt religiøst som verdsligt. Her er perspektivet set inde fra gildet selv. Flere gange møder man da også formuleringer om, at de selv har forfattet broderskabspagten, f.eks. hos købmændene i Odense

531 DGLM, II (1895-1904), s. 81.

532 DGLM, II (1895-1904), s. 62, \$25. 


\section{MEDELTIDENS GENUS}

i 1476, og det er helt rimeligt at fæste lid til sådanne udsagn. ${ }^{53}$ Men det interessante er, at selv når de formulerer en skrå selv, afviger de ikke voldsomt fra en overleveret form. Da denne form samtidig genkendes i international sammenhæng, er det rimeligt at antage, at der har eksisteret en "europæisk" prototype. En sådan kan næsten kun være formuleret af kirken. Det stemmer overens med de mange kristne formuleringer, som der gives for broderskabets nødvendighed og gavnlighed. ${ }^{534}$

Denne skarpe sondring mellem privilegiegivende skråer udstedt af byrådet eller broderskabsskråer, som formentlig i sidste instans var sanktioneret, kirken, kan erkendes fra begyndelsen af 1400-tallet. Som århundredet skrider frem udviskes de klare skel mellem de to former, formentlig fordi det fra et gildesynspunkt førte til for meget skriftlighed. I princippet burde man jo have to skråer, hvad mange sikkert også har haft, men som i længden både var dyrt, besværligt og ikke i pagt med den måde skråen indadtil blev brugt i gildet. Derfor ser man en glidende bevægelse over mod en forening af de to sider til at kunne optræde i samme skrå, dog således at opnår man nye privilegier i et gilde, så er disse udstedt af byen i særskilte breve. Her kan Ystad smede igen tjene som et eksempel. I 1506 fik de af byrådet anerkendt en udvidelse, således at de også måtte rumme guldsmede og andre håndværksarter i deres gilde. ${ }^{535}$ Det skete kun 10 år efter, at de have fået ny skrå udstedt i broderskabets ånd. Det var en og samme sag. De mange skråer, der eksisterer fra de stockholmske håndværk, og som hovedsageligt hører hjemme efter 1450, er også blandingsskråer. ${ }^{536}$

Men hvad indeholder en broderskabsskrå så? Det kan siges meget kort: masser af bestemmelser om gildedrikken. Og det er her, kvinderne træder markant ind på scenen.

\section{Kvinders medlemskab i gilderne}

Men Håkon Hauglands nye ph.d.-afhandling om de nordiske gilder foreligger der for første gang en oversigt over kendte gilder i Skandinavien. 542 gilder er på den ene eller anden måde omtalt i kilderne, flest i Dan-

533 DGLM, I (1895-1904), 736 "brødherschapps skraa.. som the gothe men, der ..[vort].. gilde først vpptoghe, dichtede oc samen satte".

534 Se videre Bisgaard (2001), s. $45 \mathrm{ff}$.

535 DGLM, II (1895-1904), s. $296 f$.

536 Skrå-ordningar (1856). 


\section{KÖN OCH SOCIAL ORGANISATION}

mark (349) og færrest i Norge (49), mens Sverige ligger i midten med 144. Disse tal er minimumstal, for så vidt som de fleste gilder på landet har benyttet sig af mundtlig overlevering. Optællingen viser også, at langt de fleste af disse gilder fandtes i de større byer, hvor differentieringen af udbuddet var størst. Hele 1400-tallet ser ud til at have udgjort en lang vækstperiode for gilder i Norden. Et vigtigt resultat hos Haugland er endvidere hans påvisning af, at gildedrikken var konstituerende for gilderne over alt i Skandinavien. ${ }^{537}$

Gildedrikken, som hvert gilde kunne havde sit navn for, var en tilbagevendende fest, som afholdtes en eller flere gange om året. ${ }^{538}$ Dens opbygning kunne variere, men idet den altid kopierede middelalderkirkens ritual for ihukommelsen af de døde, blev drikkens forløb til en velkendt struktur, ligesom tidligere medlemmer af gildet altid var "med" ved sådanne lejligheder. Da skråen ofte blev læst op under gildedrikken, og der var brygget specialøl til lejligheden, og der blev kvædet viser til ære for gildets patron, var drikken en markør af gildets sammenhold og gensidige forpligtelser. ${ }^{539}$ Dertil kom naturligvis festen i sig selv som afveksling i forhold til hverdagens slid og arbejde.

Set fra en historikers synspunkt indebar gildedrikkens kobling med de døde det væsentlige, at de hedengangne mænds og kvinders navne blev skrevet ned for ikke at blive glemt. Uden dødelister og medlemsfortegnelser over levende havde arbejdet med gilderne været langt fattigere. Det er samtidig disse lister, som gør, at kvinders deltagelse i gilderne kan forfølges på et mere detaljeret plan end på så mange andre steder i de middelalderlige skandinaviske samfund.

Haugland har gennemgået samtlige medlemslister og skilt dem ad i grupper af kvinder og mænd. ${ }^{540}$ Det vigtige resultat er, at kvinder havde adgang til alle middelalderens gildetyper. Dertil kan Haugland vise, at kvinder fra alle samfundslag er repræsenteret. Der var dronninger, adelige fruer, borgmester- og rådmandsfruer, håndsværkskoner, svendekoner, enker, jomfruer og tyende, levende som døde.

De fyldigste lister stammer fra de religiøst orienterede gilder så som

537 Haugland (2012), s. 90 og 198ff.

538 Bisgaard (2001), s. 83ff.

539 For dens forløb se Bisgaard (2001) kapitel 2 og Haugland (2012) kapitel 5.

540 Haugland (2012), s. 118-141. 


\section{MEDELTIDENS GENUS}

Corpus Christi gilder, rosenkransgilder og præstegilder, de såkaldte kalenter. Det er samtidig disse gilder, der har flest kvindelige deltagere. Der eksisterer ikke færre end 12 bevarede lister fra disse gildetyper, og det er så mange, at de ikke alle kan gennemgås her. En liste fra hver gruppe er derfor udvalgt. Det er listerne fra Guds Legemslav i Aalborg, fra rosenkransgildet i Slesvig og fra kalentet fra Flensborg. Da Guds Legemslav i Aalborg sædvanligvis opfattes som et købmandsgilde, begynder vi bagfra.

Fra kalentet i Flensborg, der blev etableret allerede i 1362, måtte der ved siden af præsterne kun være 24 lægfolk som medlemmer. ${ }^{541}$ Det begrænsede medlemstal til trods sondrede man i opgørelserne mellem mænd og kvinder. Den udaterede kvindeliste over lægfolk har mange overstregninger, som nye medlemmer i løbet af 1400-tallet erstattede gamle. Sammenholdes den med den tilsvarende for mændene, benævner den langt flere med titel end blandt kvinderne. ${ }^{542}$ Det fortæller det interessante, at kvinderne ikke kun deltog som ledsagere af deres mænd, men også kom alene. Det være sig enker eller jomfruer. Det er en vigtig iagttagelse. Medlemsskabet var altså tilsyneladende frivilligt og selvvalgt.

Blandt kvinderne kom rekrutteringen til kalentet bl.a. fra adelige kredse. Stormændenes tilstedeværelse er værd at bemærke, for den var ingen selvfølge, for så vidt som gildet var knyttet til borgernes kirke, Mariakirken, inde i Flensborg. Adelige kvinder var på den måde på udebane, men et gildes tiltrækningskraft kunne altså overskride grænsen mellem land og by. De fleste kvinder i kalentet kom dog fra selve Flensborg og tilmed fra de familier, som vi kender til. Det er næsten det samme som at sige, at kvinderne fortrinsvis kom fra byens velstånde kredse. ${ }^{543} \mathrm{I}$ lyset af de adelige kvinders deltagelse kan dette ikke overraske. Indtrykket suppleres af, at dronning Margrete også optræder blandt dødelistens navne. ${ }^{544}$ Flere af de ikke kendte kvindelige navne, kan man forestille sig, var medfølgende tjenestepiger, der på fruens foranledning kom med på dødelisten..$^{545}$ Det

541 Lars Bisgaard, 'Det middelalderlige kalente. Et bindeled mellem kirke og folk', i Agnes Arnórsdóttir, Per Ingesman \& Bjørn Poulsen (red.), Konge, kirke og samfund. De to øvrighedsmagter $i$ dansk senmiddelalder, (Aarhus 2007), s. $451 \mathrm{ff}$.

542 DGLM, I (1895-1904), s. 276 og indledningens noter s. 263.

543 Kraack, Gerhard: Das Gildewesen der Stadt Flensburg, Schriften der Gesellschaft für Flensburger Stadtgschichte e. V., 19 Kiel 1969.

544 DGLM, I (1895-1904), s. 299. Dronningens gyldne krone til en Jomfru Maria figur er omtalt s. 270.

545 Lars Bisgaard, 'Gilder og drikkehorn i middelalderen' Den jyske Historiker 85 (1999), s. $71 \mathrm{ff}$. 


\section{KÖN OCH SOCIAL ORGANISATION}

frie gildevalg skal altså sammenholdes med, at medlemmerne kom fra samfundets bedste kredse.

Rosenkransbroderskabet fra Slesvig har vedtægter fra 1484. Ufuldstændige medlemslister med 103 navne blev i sin tid trykt hos Nyrop, men Bjørn Poulsen, der har undersøgt gildet, har fundet en langt fyldigere og ældre afskrift med 500 yderligere medlemmer. ${ }^{546}$ Alene ud fra de mange navne tør man fastslå, at dette gilde var af en helt anden slags end det elitære kalente i nabobyen Flensborg. Samtidig er det muligt at opgøre kvindernes andel. Den udgør $48 \%$ af medlemmerne i Slesvig. ${ }^{547}$ Fraregner man de 62 gejstlige medlemmer, som jo pr. definition var mænd, bliver kvindernes andel af lægfolket den største. Det er påfaldende mange. I forhold til det eksklusive præstegilde i Flensborg er den sociale spredning anderledes, hvilket nærmere bestemt vil sige, at mængden af uidentificerbare kvindenavne i Slesvig er markant. Men det kan også påvises konkret. For så vidt som håndværkerhustruer og tjenestefolk direkte optræder med titel på listerne fra Slesvig.

Samme billede tegner bevarede medlemslister for rosenkransbroderskabet i Vadstena fra årene 1522-23. Her var medlemsantallet endnu større end i Slesvig og oppe på 2.350 mennesker. De 1230 var kvinder, eller $52 \% .{ }^{548}$ Poulsen finder lignende forhold hos tyske og italienske rosenkransbroderskaber og man kunne her yderligere henvise til, at Hellig Legemes gildet i Stockholm, der også var gejstligt kontrolleret, havde mange kvindelige medlemmer. ${ }^{549}$ Det var ganske vist ikke et rosenkransgilde, men Corpus Christi gilderne var også religiøse i deres formål, selvom det at gå i procession på Corpus Christi dagen ikke nødvendigvis indebar samme religiøse engagement som fremsigelse af bønner med rosenkrans. ${ }^{550}$ Disse eksempler bringer tanken hen på den kendte kirkehistoriker André Vauchezs betragtninger over kvinders betydning indenfor den kristne religion i senmiddelalderen. Denne, mener han, var stigende

546 Bjørn Poulsen, 'Fromhed og magt: Rosenkransbroderskaberne i Slesvig og Odense', i Lars Bisgaard \& Leif Søndergaard (red.), Gilder, lav og broderskaber i middelalderens Danmark, (Odense 2002), s. 195-255, DGLM, I, s. 447-453.

547 Poulsen (2002), s. 219. Nøjagtig $47.4 \%$.

548 Poulsen (2002), s. 224f., Haugland (2012), s. 125.

549 Göran Dahlbeck, I senmedeltidens Stockholm (Stockholm 1988).

550 Haugland (2012), s. 125. 


\section{MEDELTIDENS GENUS}

middelalderen igennem og værd at fremhæve i egen ret. ${ }^{551}$ Det er her vigtigt at understrege, at Skandinavien ikke synes at have adskilt sig fra de europæiske strømninger, noget som områdets svagere kildemateriale ved en første betragtning godt kunne friste en til at tro. Kun via gildernes materiale er det muligt at opnå et sådant fingerpeg for Skandinavien.

Vender vi blikket mod købmændenes gilder, er de bevarede medlemslister fire, en svensk og en fra hver af de danske byer Flensborg, København og Aalborg. Det kan diskuteres, om listerne fra Aalborg, skal forstås som et købmandsgilde, sådan som Håkon Haugland gør. Gildet var viet til Corpus Christi, og som sådan bør det placeres i gruppen af særlige religiøse gilder oven for. ${ }^{552}$ Traditionen med at forstå gildet som et købmandsgilde har dybe rødder i historieskrivningen, hvilket igen kan forklares ved dels dets manglende nedlæggelse ved Reformationen, således at det blev gjort til købmændenes mødested i Aalborg i århundreder, dels ved at den autoriserede kildeudgave på området i 1904 rubricerede det som et købmandsgilde. Denne disput skal ikke opholde os, for det vigtigste må være, hvad listerne med 2.412 navne siger om kønsfordelingen. Her er der en udpræget overvægt af mænd. Kvindeandelen er på under $2 \% .{ }^{553}$ Socialt set var gildet ellers ganske bredt funderet, idet både konger, adelige, lensmænd, biskopper, munke, købmænd, håndværkere og tjenestefolk er repræsenteret. Rigtig mange kom fra byens fyldige opland i det nørrejyske. Samlet betyder den ringe kvindelige deltagelse i gildet, at medlemskredsen ikke stemmer overens med den, vi mødte i kalenterne og rosenkransgilderne. Her er det vigtigt at erindre, at Corpus Christi gilderne mange steder i Europa, trods deres religiøse formål, især brillerede ved selskabelighed og prestige. Den ålborgensiske udgave af denne appellerede øjensynligt ikke til kvinderne, eller så har mændene ikke brudt sig om at have deres hustruer med. Vi ved, at Corpus Christi processionen i byen blev kombineret med papegøjeskydning, som jo udelukkende var for mænd, og en tilbagevendende kåring af majgrever, hvor kvinder heller ingen plads havde. ${ }^{554}$ Kvinders manglende tilstede-

551 André Vauchez, Les laïcs au Moyen Âge (Paris 1987), se også Margaret L. King, Women of the Renaissance (Chicago 1991), s. 103-130.

552 Bodil Frandsen, Til glede og salighed. Guds Legemslav i Aalborgs senmiddelalder (Aalborg 2007), s. 91.

553 Haugland (2012), s. 130. Der er 69 kvindenavne i alt.

554 Frandsen (2007), s. $71 \mathrm{ff}$. 


\section{KÖN OCH SOCIAL ORGANISATION}

værelse kan i hvert fald ikke være tilfældig, når gildet både er bredt socialt funderet, og det statistiske grundlag er så stort, som tilfældet er.

Der synes ikke at være noget fast mønster for deltagelse af kvinder i de såkaldte købmandsgilder. Den kan være ubetydelig som hos Danske Kompagni i København og hos St. Gertrudsgildet i Stockholm, men også være markant som i Vor Frue gildet i Flensborg, hvis udaterede medlemslister fra 1400-tallet omfatter 1.590 personer, hvoraf ca. $30 \%$ var kvinder. Hele 297 af kvinderne kan her ikke identificeres, hvilket indikerer, at rekrutteringen har overskredet købmandskredsen. ${ }^{555}$ Skal forskningen videre, må der fokuseres på detailstudier, for kun på denne måde kan ny viden erhverves til et ellers flimrende billede. Indtil videre må konklusionen være, at både købmandsledede gilder og religiøse broderskaber kunne have en blandet medlemsskare.

Håndværkerne leverer, næsten som forventet, de dårligste lister. Ingen af fem bevarede lister fra Norden rummer tilnærmelsesvis navnemængder som angivet oven for. 563 navne haves alt i alt, og det er kun en brøkdel af medlemsskaren alene i Corpus Christi gildet i Aalborg. ${ }^{556} 164$ af disse stammer fra bagersvendenes gilde i København, hvis skrå er dateret 1403, hvortil en udateret liste, skrevet af flere hænder, er indføjet. En egentlig medlemsliste er det ikke, men spredte optegnelser om folk, som i tiden mellem 1403 og 1540, hvorfra den sidste indførsel stammer, har haft sin gang i gildet. 29 af disse er kvinder. Kvantitativt er det $0.15 \%$. Det kan ikke blive andet end en indikator for kvinders deltagelse.

Nærlæser man indførslerne, kommer man tættere på. Ghessæ Bois søster var med, Anne, Niels Kags datter lige så, Benthe kom sammen med apotekerens Anne, Rasmus havde sin hustru med, en anden Rasmus sin moder, Her Fannes, som måske var gildets præst, medbragte sin søster Karine, Else Dreyfuss, som havde tjent en hallandsfarer, var med, og bageren Søren Thomsen tog sin hustru, Karine og sin moder og sin søn Jens og dertil Ellen og Dorothea med. ${ }^{557}$ Disse relationer kan ikke sættes på snor. Snart er familien i centrum, unge som gamle, så veninder, så tjenestefolk, så hustruen. Ægtefæller optræder faktisk kun i begrænset omfang. Det kunne vise, at farende svende endnu var ugifte, men sandheden er

555 Haugland (2012), s. 130.

556 Min sammentælling fra Haugland (2012), s. 137.

557 DGLM, II (1895-1904), s. 9-14. 


\section{MEDELTIDENS GENUS}

snarere, at bagere ikke var nogen typisk farende svend. Så hvorfor skulle bofaste bagersvende ikke have deres hustruer med? Forklaringen er formentlig, at listen rettelig bør ses som en gæsteliste eller en hverveliste, og ikke som en medlemsliste. Den pointe står dog tilbage, at kvinders deltagelse $\mathrm{i}$ et håndværkergilde kunne ske af mange grunde og ikke lå fast på forhånd. Kvinders gang i gilderne var altså også her et frivilligt anliggende og ikke betinget af relationer, der lå fast på forhånd.

De fyldigste lister fra håndværkerkredse stammer fra Dragerlavet $\mathrm{i}$ Flensborg. Det er Hauglands fortjeneste at have fulgt Kraack og sat dette gilde i relation til håndværk. Listerne, som blev påbegyndt i 1399, havde skriveren bestemt skulle rumme fire kategorier af medlemmer: først consulum viuorum/levende rådmænd, presbiterorum/præster af alskens slags, vivuorum fratrum/levende brødre og sororum viduarum/søstre der er enker. Systemet brød imidlertid sammen og erstattedes af først tilføjelser, der ikke stemmer overens med overskriften, siden årlige indførsler. ${ }^{558}$ Det bemærkelsesværdige er naturligvis, at enker er tiltænkt deres egen liste. Det er en understregning af enkernes stærke placering i håndværkerkredse, og en støtte til Grethe Jacobsens syn på disse. Men overskriften indikerer jo også, at enkerne kun er en delmængde af kvinderne. Hvor er resten af kvinderne da henne? Under "brødre" naturligvis. Alle hustruer er på Dragerlavets lister opført som brødre. Ud over endnu engang at erindre os om broderskabstankens styrke, fortæller det noget mindst lige så vigtigt. I et håndværkergilde er mand som kvinde tilsammen identisk med mesterembedet. Altså familia-tanken i sin kerne. Manden repræsenterede i kraft af sin værnemyndighed embedet ud af til og skulle forsvare det, men indadtil overfor svende og lærlinge, delte han det med hustruen. På den måde var hun var fuldgyldig del af embedet. Her stod mand og kvinde lige.

Listens respekt for hustruen smitter gunstigt af på den kvinderatio, som vi kan få frem for Dragerlavet. Blandt 288 navne er 127 kvindelige. Det vil sige ca. $45 \%$. Trækkes 19 præsters navne ud, er kvindernes andel knap halvdelen. En formentlig troværdig procentsats for et håndværkergilde. Og et stærkt argument for, at bagersvendenes tilfældige lister fra København ikke på nogen måde er medlemslister.

De resterende tre lister er med hensyn til kvinderepræsentation mindre

558 DGLM, 1 (1895-1904), s. 552-56. 


\section{KÖN OCH SOCIAL ORGANISATION}

interessante. Den kan de nemlig ikke sige noget om. Derimod nok noget om kvinders indflydelse på andre områder af et håndværkergildes virke. Fra det tyske skomagergilde i Bergen eksisterer der en liste fra året 1451 med 62 mandsnavne. Listen registrerer, hvem der har været til stævne pågældende år. Da stævnet er stedet, hvor beslutninger tages, og beslutninger selvfølgelig tages af mænd, ville alt andet end mandsnavne have været mistænkeligt. At bruge listen til at sige noget om kvinders deltagelse i skomagergildet, giver ingen mening. ${ }^{559}$ Selv om nogle af skomagerembederne i Bergen skulle have været besat af enker i 1451, ville det have været deres værger, som repræsenterede dem til stævne.

Fra bagerne i Malmø haves en donationsliste fra tiden o. 1500. Selvom listen kun er på ni navne, er der ikke desto mindre fire kvinder blandt. Donationerne er givet $\mathrm{i}$ forbindelse med en indsamling til gildets alter. Trods de få navne fortæller listen noget væsentligt om kvinders plads i tidens religiøse liv. Endelig er der fra smedene i Ystad bevaret en dødeliste. Den indeholder som tidligere anført udelukkende mandsnavne, af hvilke en betragtelig del bærer den forklarende titel faber/smed. I lyset af de ret differentierede lister fra de gilder, vi hidtil har mødt, og i lyset af at smedenes egne vedtægter opererer med kvinders adgang ${ }^{560}$, er det rimeligst at betragte listen som et fragment og ikke som et udtryk for smedegildets hele medlemsstruktur.

Gennemgangen har vist, at kvinders deltagelse i gilderne både kunne være frivillig og obligatorisk. Det frivillige aspekt dominerede i de religiøse broderskaber, og kunne her resultere i at nogle gilder havde flere kvinder som medlemmer end mænd. Den anden yderpol er håndværkergilderne, hvor kvinder i kraft af at være mesters hustru var fødte medlemmer af gildet. Alligevel er der også frivillig deltagelse i håndværkergilderne, hvad gæstelisterne til bagersvendenes gilde i København viser. Købmændenes organisationer tegner et mere flimrende billede med store svingninger for kvinders deltagelse. Men var håndværkerhustruen selvskreven må købmandens også have været det, og det kunne kalde på en mere tilbundsgående undersøgelse af materialet med en kritisk distance til de nedarvede klassifikationer. Resultatet her er opnået ved ikke at godtage den første og

559 Haugland (2012), s. $135 \mathrm{ff}$.

$560 \$ 22$ Item hwilken qwynne $i$ thatthe worth laff wil gaa, giffwe til laghet ij grote och en marcth wox. DGLM, II (1895-1904), s. 270. 


\section{MEDELTIDENS GENUS}

bedste liste fra et gilde, som en fuldstændig medlemsliste, men som levn fra en differentieret virkelighed. Den vigtigste enkeltfaktor heri er gæsteinstitutionen ved de årlige gildedrikke. Tiden er kommet til at undersøge denne nærmere.

\section{Gæster}

Det var gildemedlemmer tilladt at invitere gæster til gildedrikken. Reglerne herfor er gerne eksplicitte i skråerne, og man må en gang imellem undres over, at man vier punktet så stor opmærksomhed. Flere årsager kan ligge bag. På den ene side var gæster i sin kerne potentielle nye medlemmer, og i et hvilket som helst foreningsliv er fortsat rekruttering et vigtigt omdrejningspunkt. Med væksten i antallet af gilder i senmiddelalderen in mente, bl.a. forårsaget af deres spredning på endnu mindre grupper end tidligere - bagersvendene i København fik jo, som vi har set, eget gilde i $1403^{561}$-, må gæsteinstitutionen have fået en endnu mere central rolle i at sikre gildets fortsatte beståen. Hvis der blev flere gilder, må konkurrencen imellem dem også være blevet større, og det vil så igen kunne forklare en større opmærksomhed på at indbyde gæster. Men man forstår også af bestemmelserne, at gæster ikke kun betød penge i kassen her og nu eller i fremtiden. Gæster kunne ved deres blotte tilstedeværelse afstedkomme uro. Overholdt de gildets skrevne og uskrevne regler? Hvordan reagerede de, når de fik serveret velbrygget øl, måske tilmed i store mængder? Og hvor mange gæster måtte forskellige medlemmer af gildet invitere? Stod alle i gildet ens, eller kunne forskellig social status berettige til at skelne mellem gæsternes antal? Og hvem var ansvarlig for ødelæggelser; gæsten selv, eller den der havde inviteret? Gæster var med andre ord et tveægget sværd. De repræsenterede både økonomisk vækst og potentiel uro og ballade.

Grsteinstitutionen i gilderne er gammel. Allerede i Skt. Knudsgildet i Malmø, hvis skrå er fra o. 1300, findes den beskrevet, først på latin siden dansk. Først formanes den broder, der vil invitere en gæst, at han skal meddele det til oldermanden, dernæst, at gæster kun må komme på gildedrikkens første og anden dag og ikke den tredje (her lå formentlig det besluttende stævne). Men ikke alle og enhver kan inviteres som gæst. Folk, der har udeståender med gildet eller et medlem, er forment adgang.

561 I Sverige fik sadelmagersvendene skrå engang før 1437. Skrå-ordningar (1856), s. 1. 


\section{KÖN OCH SOCIAL ORGANISATION}

Når gæsten så møder frem, skal han sidde hos den broder, der har indbudt, og denne skal være garant for hans indskud til øllets brygning og for skader, der måtte opstå i gildehus eller gildegård. ${ }^{562}$ Sådan skriver kun det gilde, der allerede har erfaring med gæster.

Gæsteregler er sjældent så eksplicitte som her, men knudsgildets bestemmelser er som en nøgle til mere prosaiske og kortfattede statutter hos andre gilder. Generelt tør man hævde, at princippet gælder, at den inviterende er garant for sin gæst, økonomisk såvel som moralsk. Hvem kan så invitere? Oftest står der kun broder, men som tidligere erfaret kan det jo betyde både broder og søster. Det gælder øjensynligt også i dette tilfælde, tør man tro knudsbrødrene i Malmø. Allerede o. 1400 føjede de to bestemmelser om gæster ind i deres optegnelsesbog. De lyder:

Item skall och ingen broder eller søster biude nogen giæst uden dend, som gudsfrycht hafuer och werdig er at vorde brodere eller søster i gilldet ..... Item schall och ingen broder eller søster sætte nogen giæst til bords, førind hand spørger aaldermanden ad. ${ }^{563}$

Dette er ingen selvfølgelig ret for kvinderne, for med mandens værgepligt in mente burde denne så ikke bevare kontrollen med tilgangen til et gilde? Men dette princip er altså veget for princippet om, at brødre og søstre er hinandens lige. Købsvendene i Randers har samme eksplicitte bestemmelse i året 1417, og selv Corpus Christi gildet i Aalborg, som aldrig formåede at tiltrække kvinder, har bestemmelsen. ${ }^{564}$ Kvindeinviterede gæster møder vi i praksis hos en række gilder, uden at pågældende gildes bestemmelser siger noget om, hvem der kan invitere. I afsnittet ovenfor mødte vi f.eks. Bente, der mødte op med apotekerens Anne (note 156), i kalentet i Flensborg tog en frue sin tjenestepige med (note 544), og hos rosenkransgildet i Slesvig står kvinder som garant for andre kvinder. En af de kvindelige donatorer i Malmø bagerlav, som gav penge til

562 DGLM, I (1895-1904), s. 71, \$7 og s. 91, \$6.

563 DGLM, I (1895-1904), s. 165, $\$ 5$ og $\$ 4$. Bemærk at ”han ” her dækker begge køn.

Samme tendens findes i det svenske materiale, se. f.eks. citatet før note 571.

564 DGLM, I (1895-1904), s. 565 og 626. 


\section{MEDELTIDENS GENUS}

gildets alter, hed Eline Låsesmeds. ${ }^{565}$ Hun må i tidernes morgen være begyndt som gæst i gildet, for bagerske var hun i hvert fald ikke, og dog kunne hun give gaver og føles sig som fuldgyldigt medlem. Et lignende engagement møder vi hos en vis Helene, som rejste det halve Jylland igennem i året 1471 , for at komme til gilde i Ribe. ${ }^{566}$

Kvinder havde altså ret til at invitere gæster, og de gjorde det i praksis. Når vi ovenfor har set, at der var gilder, som kvinder øjensynligt ikke brød sig om at komme i, mens de i andre gilder kunne udgøre hovedparten, rummer gæsteinstitutionen og dens mulighed for hvervning af nye medlemmer en teknisk forklaring på, at gilder kunne udvikle sig så forskelligt. Den har kvinder som mænd udnyttet.

Et indtryk af gæsteinstitutionens omfang leverer Skt. Lucii gildet i Roskilde. Hverken dets skrå eller alder er kendt, men et lille hæfte med navne på dets medlemmer og regnskaber er overleveret for udvalgte år mellem 1483-1524. Heri er også indføjet gæstelister. I året 1518 var der på gildedrikkens første aften 23 gæster. 10 stillede hver for en gæst, tre for to gæster, en for tre og en for fire. Om otte af disse står tilskrevet, at de blev brødre i gildet ved den lejlighed. Ingen af gæsterne er navngivet, og de omtales kun som fratres. Nogle af disse har givetvis været skjulte sorores. På gildedrikkens anden aften kom 17 gæster hidbragt af 11 stillere. På gildets tredje aften kom seks gæster medbragt af hver sin stiller. En blev broder. ${ }^{567}$ Af 46 gæster til en gildedrik blev ni altså fuldgyldige brødre. Desværre kan vi ikke opgøre, hvor mange medlemmer gildet havde, men selv uden at kende den procentuelle andel, er tallene store nok til at give en fornemmelse af gæsteinstitutionens betydning for gilderne.

\section{Gildedrikkens afvikling}

Første led i forberedelserne til festen var at få brygget eget øl. Mange gildeskråer fortæller nøje, hvornår brygningen skal gå i gang, og hvem der har opgaven. Det interessante i denne sammenhæng er, at dette aldrig

565 'Regnskabsbog for Malmø bagerlav St. Antonii gilde 1496(93)-1552', i Lars Bisgaard \& Leif Søndergaard (red.), Gilder, lav og broderskaber i middelalderens Danmark (Odense 2002), s. 298.

566 Ribe Bys Historie 1 710-1520, red. Søren Bitsch Christensen (Esbjerg 2010), s. 286, DGLM, I (1895-1904), s. 348.

567 DGLM, I (1895-1904), s. 410-413, Thelma Jexlev, 'Sankt Lucii gilde I Roskilde: Et bidrag til Roskildes sociale historie o. 1500', i Lars Bisgaard \& Leif Søndergaard (red.), Gilder, lav og broderskaber i middelalderens Danmark (Odense 2002), s. 173-194, har undersøgt listerne prosopografisk. 


\section{KÖN OCH SOCIAL ORGANISATION}

involverer kvinder. I hvert fald ikke, når det gjaldt om at bedømme, om det bryggede $ø l$ var godt nok. ${ }^{568}$ Denne opgave blev betroet mænd. Hvem der varetog selve brygningen, står der til gengæld intet om, og da det på gårdene ofte var kvinder, kan det samme have været gældende i gilderne. Når øllet var brygget, og festen indkaldt til de dage, som skrån havde fastsat, skulle stedet for gildedrikken falde på plads. Det skete efter et sindrigt system, hvor opgaven i håndværksgilderne gik på omgang mellem embedsbrødrene, mens religiøst betingede gilder ofte havde fast mødested, enten ved en kirke eller i eget gildehus. Det gjaldt f.eks. Corpus Christi gildet, (Guds Legemslav) i Aalborg, hvis sal var så stor, at den kunne udlejes til bryllupper. ${ }^{569}$

Det er ikke tanken her at gennemgå gildedrikkens forskellige led men at fokusere på, hvad vedtægterne siger om mænd og kvinders adfærd og gøremål under festen. Der ligger en fare i at løsrive dette aspekt fra det konkrete forløb, men det er svært at få gangen på plads i detaljer, fordi det forudsættes bekendt. Denne tavshed er endnu et argument for gildedrikkens rituelle opbygning, da faste og genkendelige former er kernen i et ritual, selv om man selvfølgelig må regne med variationer på det mindre plan fra gilde til gilde. Derfor kan man som historiker risikere ingen vegne at komme, og helt tabe kønsaspektet af syne ved en sådan minutiøs fremgangsmåde. I det følgende er den eksisterende litteratur fulgt om gildedrikkens forløb. ${ }^{570}$

Den første aften var som regel den religiøst mest mættede. Her blev skråen læst op, her ærede man gildets helgen eller helgener, og her blev de døde af gildet mindet. Et vigtigt led heri var at drikke mindeskåle. Kun en sjælden gang får dette forløb, der naturligvis forudsættes bekendt, en kønsdrejning. Det sker i skråen for Skt. Katarina gildet på Gotland fra 1443. Her skulle der drikkes tre mindeskåle: en for Kristus, en for Jomfru Maria og en for Skt. Katarina. Det bemærkelsesværdige er, at brødrene

568 DGLM, I (1895-1904), s. 225. Købmændene i Flensborg har direkte en bestemmelse om, at flere skal mødes forud for at vurdere øllets kvalitet. Det samme gælder skomagerne fra Stockholm (før 1474), se Skrå-ordningar (1856), s. 26, \$52.

569 Gildesalen her var så stor, at den blev lejet ud til bryllup (fæsteøl) for bl.a. adelige. DGLM, I (1895-1904), s. 631.

570 Haugland (2012), s. $145 \mathrm{ff}$, Bisgaard (2001), s. $83 \mathrm{ff}$. 


\section{MEDELTIDENS GENUS}

skal synge for Kristus, søstrene for Vor Frue og for Skt. Katarina. ${ }^{571}$ En sådan kønsspecifik henvendelse til Jesus, Maria og gildets særlige værnehelgen giver vældig god mulighed for identifikation, og placerer kønnet som en vigtig brik i omgangen med de hellige personer. Det rummer i det hele taget en dimension til forståelse af det religiøse liv, som der har været for lidt fokus på. Imidlertid nævnes en sådan adfærd kun på Gotland, og det er vanskeligt at vide, om det er en særordning, eller den har haft en bredere praksis i gilderne.

Gildeskråerne har rigtig mange bestemmelser om øldrikning, men ulejliger sig sjældent til at præcisere, hvilken man har i sinde. Det har været årsag til mange misforståelser om gildedrikken. Som hovedregel kan man sige, at den højtidelige mindedrik synes at være sket med de bedste bægre eller kostbar horn, mens den almindelige selskabelige øldrikning bare fandt sted og ikke krævede særlige former. De mange bestemmelser munder næsten altid ud i bøder for ikke at måtte gøre dette eller hint. Om bøderne er møntet på den første aftens højtideligheder eller hører hjemme under den fortsatte fest de følgende dage, er et studium i sig selv, og skal ikke opholde os. Sagen er, at langt hovedparten af bødebestemmelserne er udfærdiget med en "broder" som den handlende, og det rejser det klassiske problem, om termen skal forstås som møntet på manden eller i en generel og kønsneutral betydning. Ser man det store svenske og danske materiale under et, hænder det, at kvinder og uhæmmet drikning er knyttet sammen. Det sker f.eks. hos tømmermandsgildet i Stockholm anno 1454 med disse ord:

Hwilken Broder eller Syster sin Bäker spiller, så at han kan thet ey hölia medh sin Hand, böte fire Penninga för hwar beker eller kaar.

Hvilken Broder eller Syster så drucko, at han eller hun vpkaster i gildis hwset, böte halff mark penninga, gör han eller hun thet vthe i Förstuve eller i Gården, böthe tre öre penninge. ${ }^{572}$

571 Småstycken (1868-1881), s. 150 "Och skulu skänkias triär minnä, brydr, wars herra minnä, ock sustr waru Fru minnä, ock Sancta katherina minne". Det kan også forstås således, at det sidste minde blev sunget og drukket af begge køn, da der er et komma foran.

572 Småstycken (1868-81), s. 22f., \$27 og 19. 


\section{KÖN OCH SOCIAL ORGANISATION}

Begge bestemmelser kan genfindes hos skomagerne og buntmagerne i Flensborg, hvis søstre påmindes om det samme, men ellers ses bestemmelserne kun med en broder som den handlende. ${ }^{573}$ Fremhævelsen af søstrene hos tømmermandsgildet skyldes formentlig, at det socialt skilte sig ud fra mængden. Miljøet her kan have været hårdt. F.eks. stadfæster flere af de mange andre stockholmske gilder, at kun ærbare og skikkelige kvinder kunne blive medlemmer af deres gilde. Denne bestemmelse er på ejendommelig vis blødt op hos tømmermændene, for de skriver, at brødre eller søstre med et ondt rygte må sidde hjemme, indtil gildet sender bud efter dem. ${ }^{574}$ En tolkning kunne være, at disse ikke ved deres tilstedeværelse skal ødelægge mindedrikkens kraft, men når denne er vel overstået, kan de godt møde op. Gildet har derudover to andre bestemmelser, som er lige så unikke. De lyder:

The Dannequinnor .. som skänkia, them diarffz ingen ojhöffuitzlighen til tala eller ohöffuitzlighen taga, hoo thet gör böthe ett halff pund Wax.

Fins någor i wårt Company som låckar och skämmer sins Brodhers hustru, Dotter, fräncko eller mägd, och wardher til witnadher medh tweem Brödrom, han ombäri wort Compani och Selskap, sammaledes ware om then som någher aff thesso förnempdom wåldtagher. ${ }^{575}$

Det samlede indtryk er, at tømmermændenes gilde i Stockholm ikke placerede sig i byens mainstream af gilder men tilhørte en niche. At føje et "søster" til broder gav således mening, og den sociale sideplacering kan forklare, hvorfor gildet var eksplicit om ting, der sædvanligvis blev tiet ihjel. Derimod kan man ikke laste de to håndværkergilder fra Flensborg på nogen måde. Det indtryk, der står tilbage, er derfor, at også kvinder kunne gå over stregen i gilderne. De udgjorde immervæk hen ad halvdelen af alle medlemmer, og vi har set, at de var med til at udbringe

573 DGLM, II (1895-1904), s. 92 f. og 108. For den mere gængse med "broder som handlende, se f.eks. Skrå-ordningar (1856), s. 108, \$30, murerne i Stockholm 1487.

574 Småstycken (1868-1881), s. $21 \$ 13$.

575 Småstycken (1868-1881), s. 22 og $24, \$ 22$ og $\$ 42$. 


\section{MEDELTIDENS GENUS}

mindeskålene og synge for gildets patron eller patroner. Drikken var jo religiøs i sin kerne, og derfor var den for alle. Øldrikning for kvinder var blot ikke noget omstridt felt, så længe den var behersket i indtagelsen. Og det har den øjensynligt mestendels været for kvinderne, siden kun få gilder har bemærkninger om dem.

1400-tallets almindelige vækst i gildernes antal må have betydet, at vindene blæste for fastere regler for broderskabernes moralske habitus. ${ }^{576}$ Håndværkere skulle være ærlige, deres hustruer ligeledes og dertil af ægte fødsel. ${ }^{577}$ For at komme med i gejstlighedens eftertragtede gilder, skulle kvinderne være uberygtede, og mange håndværkergilder fulgte trop. ${ }^{578}$ Kvinder som mænd med embede skulle netop være, som ordet siger, godtfolk. Bjørn Poulsen har fremdraget en retssag fra 1511, hvor en tyv mistede retten til at omgås "retskafne folk, gilde og lav". ${ }^{779}$ Gildets fællesskab var blevet respektabelt og udtryk for et hæderligt liv og virke. Derfor blev det hyldet, og derfor skilte de sig overordnet ikke ud fra det gode selskab. Selv noget så dagligdags som at behandle sine tjenestefolk ordentligt kunne komme på gildets agenda for omgangsformer. Således skal hverken broder eller søster, der er til gilde, lade sin dreng eller pige stå og vente, mere end ærindet berettiger til. ${ }^{580} \varnothing \mathrm{l}$ skulle bringes ud, når søster eller broder var syg, og ikke kunne møde til gilde, ligesom at våge hos den syge kan komme på tale. ${ }^{581}$ Det var alt sammen ordentligt.

Omgangsformerne mellem kønnene i gildet er kun sjældent belyst i skråerne. Et udtryk som en "søsterbænk" kan dukke op og fortælle om, at mænd og kvinder kunne være bænket efter køn. ${ }^{582}$ Social status var en anden adskillelse. Gerdbrødrene, som stod for gildedrikkens afvikling, eller stolsbrødre og oldermand, der hørte til gildets ledelse, måtte ikke

576 Jacobsen (1995), s. 238f.

577 Skrå-ordningar (1856), s. 213, $\$ 40$, bagerne i Stockholm ” inge berychtade qwinnor skole och ware i samma Embetet." I det danske materiale er kravet en så stor selvfølgelighed, at det giver mere mening alene at henvise til de gilder, der kræver brev på ægte fødsel. DGLM, II (1895-1904), s. 71, 80, 88, 193, 286 og med besegling 103, 152, 216 og 416.

578 DGLM, I (1895-1904), Kalentet i Stuntebøl, s. 498, \$1, og gæsterne skal også være gode og hæderlige, Kalentet i Køge, s. 458, \$8. For håndværk jf. note 576 oven for.

579 Bjørn Poulsen, 'Dagliglivets fællesskaber', i Per Ingesman, Ulla Kjær, Per Kr. Madsen og Jens Vellev (red.), Middelalderens Danmark (København 1999), s. 188-207, her s. 190.

580 Skrå-ordningar (1856), s. 83. Murene i Stockholm 1487.

581 For religiøst relaterede gilder DGLM, I (1895-1904), s. 435, 496f. og 500. Blandt håndværkere er bestemmelsen så almindelig, at henvisninger vil sprænge alle rammer.

582 Skomagerne i Sønderborg 1488. DGLM, II (1895-1904), s. 196, \$18. 


\section{KÖN OCH SOCIAL ORGANISATION}

forstyrres i deres gerning, eller afbrydes, når de talte. Heller ikke dengang har kvinder - og mænd - haft det let med at tie i forsamlinger. ${ }^{583}$

Har analysen afdækket et fast mønster, en rygrad i gildedrikkens afvikling, så er det vigtigt at huske på, at gildedrikken netop var - en fest. Festen er kendetegnet ved at rumme grænseoverskridelsen i sig. Fest er noget andet end dagligdagen, og fastholder den kun reglerne fra hverdagen, bliver det aldrig en god fest, hvis de ikke samtidig udfordres. Sagt på en anden måde, så levner festen mulighed for, at et menneskes svaghed kan vises frem, uden at han eller hun af den grund taber ansigt. Det skal ikke forveksles med karnevallets ide om at vende verden på hovedet, for i karnevallet kender de agerende ikke nødvendigvis hinanden. Det gør de ved gildedrikken - mest ved lavenes fester, i mindre grad ved de religiøst betonede fester. Netop ved at kende hinanden på forhånd kan den enkelte - mand som kvinde, mester som svend - undervejs tillade sig at overskride de vante omgangsformer. Vel at mærke på de rigtige tidspunkter. Ikke under det højtidelige øjeblik, men i den afslappende stund efterfølgende. Lærlinge og svende prøvede måske for første gang at få stærkt øl i større mængder, samtidig med at mester også var til stede. Fleres øjne kunne falde på den samme kvinde, jalousi kunne blive næret. Historierne, man kan digte, er nærmest uendelige, men de har helt sikkert fundet sted og måske også overgået fantasien.

I skråerne ses det grænseoverskridende element både direkte og indirekte. Direkte i selve påbuddets art. Man må ikke sove på bænken, man må ikke gå til øltønden og skænke selv, man må ikke tisse inde i huset, man skal tie, når oldermanden taler, man må ikke slås, osv. Igen er disse påmindelser så gængse i gildernes love, at henvisninger vil sprænge alle rammer. $\mathrm{Og}$ indirekte ved de mange almene våbenforbud under festerne. Knive, økser og andre våben er bandlyst. Sådanne gjorde ondt værre, hvis uheldet var ude.

De to slags påbud skal ses sammen. Tolkes den første gruppes forbud for sig, kan de ses som et slet skjult tilskud til gildets økonomi og som værende af ren selskabelig art. Heri er der givetvis en pointe, men kobles de to slags regler sammen, ser man også et reelt ønske om at afværge ulykker. Vold i middelalderen var en reel trussel mod fællesskaber. Den var også til stede i gilderne, og man måtte værne sig imod den. Vold kom in-

583 Igen utallige henvisninger i det danske materiale. 


\section{MEDELTIDENS GENUS}

defra og kunne ramme selv den mest respekterede i gruppen. Således indgav en præst en dispensationsansøgning til pønitentiariet i Rom i 1466, fordi han under en gildefest i en mindre by i Odense Stift var kommet til at slå en anden mand ihjel. ${ }^{584}$ I Odense fik de ny gildeskrå i smedelavet i 1496, fordi den gamle havde ført til vold og ufred. ${ }^{585}$ Og ligesom problemerne med øl ikke kun skal ses som mandens problem, skal vold heller ikke kun ses som mandens. Hos købsvendene i Randers indskærpes det direkte, at hverken broder eller søster må bære kniv eller sværd. ${ }^{586}$ Dette er dog så usædvanligt, at det kun ses dette ene sted.

\section{Afslutning}

Gilderne udgjorde ikke en rå bund i de skandinaviske samfund præget af en særlig folkelig attitude, sådan som ældre civilisationshistorisk forskning og modkulturens forskning i 1970erne har villet se dem. Netop ved at anskue gildet som en mødested kan man vise, hvor integreret gilderne var i samfundet. Intet siger dette tydeligere end Hauglands kvantitative opgørelser. Fra de relativt få bevarede medlemslister (21 i alt), der stammer fra en brøkdel af de kendte gilder, kan en simpel optælling vise, at de 21 forskellige husede ikke færre end 13.993 mennesker. ${ }^{587}$ Selv om nogle af gilderne med medlemslister sikkert var større end det gennemsnitlige gilde, er det alligevel svimlende tal, man når, hvis man dividerer med 21, trækker en vis overbelægning fra og ganger med 543. Ingen vil herefter kunne hævde at gildeinstitutionen var uvæsentlig i tiden fra Den sorte Død til Reformationen.

I samtlige lister har det samtidig kunnet konstateres, at medlemsskaren socialt set overskred hovedformålet med gildets virke. Det kan kun tolkes sådan at gilderne tilbød en platform, hvor folk kunne blandes. Når hovedparten af disse gilder tilmed tilbød frivillige ordninger for medlemskab og have en populær gæsteinstitution som et af sine tilbud, har 1400-tallets skandinav, mand som kvinde været til fest i et gilde på et eller andet tidspunkt.

584 APA (=pönitentiariats arkiv, Archivio della Penitenzieria Apostolica), Reg. Matrim. et Div. 14, fol. 124r. Venligst oplyst af Kirsi Salonen. Landsbyen er formentlig Melby i Skovby Herred på

Fyn. Det er helt ukendt, at der her skulle have været et gilde.

585 DGLM, II (1895-1904), s. 243.

586 DGLM, I (1895-1904), s. 562, \$10.

587 Min optælling på baggrund af Hauglands lister, s. 120, 125, 130 og 137. 


\section{KÖN OCH SOCIAL ORGANISATION}

Alene ved sit omfang vil gildeinstitution være af betydning i et kønsperspektiv. Der har i undersøgelsen her været lagt vægt på kvinders mulighed for selv at vælge gilde. Det er sket for at gøre op med den misforståelse, at alt væsentligt på forhånd var planlagt i de gamle samfund, hvor mænd som kvinder så at sige "kun" skulle leve en forudbestemt rolle ud. En sådan forståelse overser så ganske, at det kunne ske på lige så mange måder, som der var individer, og at personlige præferencer altid har spillet ind. Vi har set, hvordan kvinder ofte fandt religiøst definerede gilder attraktive, ligesom religiøse opgaver i almindelige gilder direkte kunne knyttes til kønnet. Kvinder kunne være garant for en god bekendt og hverve denne som medlem, ligesom mænd kunne. Friheden heri, og det vil sige magten til at sætte sit præg på eget liv, erkendes ikke, hvis man kun ser på samfundets overordnede magtfordeling og forestillinger om det gode liv.

Det siger sig selv, at de populære gilder ikke har kunnet opretholde adfærdsmønstre eller normer, som væsentligt har skilt sig ud fra det alment kendte i samfundene. På den måde af de klart en del af samfundets herskende diskurser. Men ikke nødvendigvis kun som et bevarende element. En central diskussion om gildedrikkens funktion har været og er, om den skal anskues bevarende eller frisættende. Bevarende var den jo derved, at den i sit sigte bekræftede gildets eksistensberettigelse og herskende interne orden, men frisættende var den for så vidt også. Det religiøse ritual overskred jo både $\mathrm{d} ø \mathrm{~d}$ og sociale skel, ligesom festen altid rummede muligheden for at leve sig selv ud. Hvis synsfeltet hæves til at berøre broderskabets plads i samfundet som sådan, er der næppe tvivl om, at nogle af gilderne politisk havde et arsenal, der kunne udfordre det bestående. Dette bliver erkendt om ikke før ved Reformationen, hvor broderskabernes politiske ambitioner blev en af de store tabere.

Den samme dobbelthed ses også, hvis kønnet anskues i lyset af gilderne. Da gildeinstitutionen trådte ind på skriftlighedens arena i slutningen af 1100-tallet, var der kun et agerende "broder" tilstede i skråerne, hvis læseren for en stund vil gå med til at glemme skråens begravelsesregler. Omkring år 1500 var "broder" på en lang række punkter udfordret af "søster". Men er det udtryk for kvindelige sejre, eller er det skriftlige tydeliggørelser i et mere effektivt samfund?

På det grundlæggende niveau er selve kønnet vel uden for debat i gilderne. Mand og kvinde gør hver sit, for sådan er det bedst. Det er i hvert 


\section{MEDELTIDENS GENUS}

fald bemærkelsesværdigt, at en fællesterm som "gildesøskende" aldrig udfordrer "broder" eller "søster" men forbliver en parentes i 1400-tallets vilde gilderidt. ${ }^{588}$

588 Småstycken (1868-1881), s. 147, $\$ 57$. 